J. Dairy Sci. 95:4747-4759

http://dx.doi.org/10.3168/jds.2011-4940

(C) American Dairy Science Association ${ }^{\circledR}, 2012$.

\title{
The effect of $\mathrm{NaCl}$ substitution with $\mathrm{KCl}$ on Akawi cheese: Chemical composition, proteolysis, angiotensin-converting enzyme-inhibitory activity, probiotic survival, texture profile, and sensory properties
}

\author{
M. M. Ayyash, ${ }^{*}$ F. Sherkat, $†$ and N. P. Shah ${ }^{*} \ddagger^{1}$ \\ ${ }^{*}$ School of Biomedical and Health Sciences, Victoria University, Werribee Campus, PO Box 14428, Melbourne, Victoria 8001, Australia \\ †School of Applied Sciences, RMIT University, PO Box 2476, Melbourne, Victoria 3001, Australia \\ ¥Food and Nutritional Science-School of Biological Sciences, The University of Hong Kong, Pokfulam Road, Hong Kong
}

\begin{abstract}
The effect of partial substitution of $\mathrm{NaCl}$ with $\mathrm{KCl}$ on Akawi cheese with probiotic bacteria was investigated during $30 \mathrm{~d}$ of storage at $4^{\circ} \mathrm{C}$. Chemical composition, the survival of probiotic and lactic acid bacteria, proteolytic activity, and texture profile analysis were analyzed and sensory analysis was carried out to determine the effects of substitution. No significant differences were observed in moisture, protein, fat, and ash contents among the experimental Akawi cheeses at the same storage period. Significant differences were observed in water-soluble nitrogen and phosphotungsticsoluble nitrogen between experimental cheeses at the same of storage period. No significant difference was observed in the growth of Lactobacillus delbrueckii ssp. bulgaricus between experimental cheeses at the same storage period. However, the growth of Streptococcus thermophilus, Lactobacillus casei, and Lactobacillus acidophilus was significantly affected among experimental cheeses. A significant difference was observed in soluble Ca among experimental cheeses at the same storage period. In general, no significant differences existed in hardness and adhesiveness among experimental cheeses at the same storage period. No significant differences existed in sensory attributes, including creaminess, bitterness, saltiness, sour-acid, and vinegar taste among experimental Akawi cheeses at the same storage period. Key words: Akawi cheese, $\mathrm{NaCl} / \mathrm{KCl}$ mixture, proteolysis, probiotic
\end{abstract}

\section{INTRODUCTION}

White brined cheeses produced in the Middle Eastern region are classified as rennet-coagulated cheeses with (Halloumi and Akawi cheeses) or without (Nabulsi cheese) starter culture. High salt content is a common

Received September 16, 2011

Accepted June 1, 2012.

${ }^{1}$ Corresponding author: npshah@hku.hk characteristic that Middle Eastern cheeses possess (Abd El-Salam and Alichanidis, 2004). Akawi cheese is commonly consumed in Jordan, Syria, Palestine, and Lebanon (Tamime, 2006). Akawi cheese is usually consumed with breakfast and dinner. Traditionally, Akawi cheese is produced from pasteurized bovine or ovine milk (or a mixture of both). For Akawi cheese making, the milk is pasteurized $\left(\right.$ at $60^{\circ} \mathrm{C}$ for $30 \mathrm{~min}$ or $72^{\circ} \mathrm{C}$ for $15 \mathrm{~s}$ ), cooled to about $35^{\circ} \mathrm{C}$ and then starter culture is added $(1.5 \%)$. After $1 \mathrm{~h}$, rennet is added to coagulate milk within an hour. The curd is cut, whey drained, and curd pieces are wrapped in cheesecloth in small portions (150 to $250 \mathrm{~g}$ ), pressed for about $1 \mathrm{~h}$, and brined in approximately $10 \%$ brine solution at $4^{\circ} \mathrm{C}$. In general, Akawi cheese contains about 51.0\% moisture, $21.6 \%$ fat, $22.5 \%$ protein, and $5 \%$ ash. Storage of Akawi cheese in brine solution is a critical step for maintaining quality and safety during 1 mo of storage. Because of the high salt content and health concerns, Middle Eastern people avoid consumption of Akawi cheese because of a positive correlation has been found between high sodium (Na) intake and hypertension (Kotchen, 2005), osteoporosis (Heaney, 2006), kidney stones (Massey, 2005), and cardiovascular diseases (Penner et al., 2007). The World Health Organization (Geneva, Switzerland) has recommended reducing salt in all food types to reduce health issues associated with high intake of salt (WHO, 2007). Several studies have reported that dairy products, especially cheeses, contribute to a noticeable amount of daily sodium dietary intake (Guinee, 2004a,b; Tamime, 2006). Cheese contributes to about $4 \% \mathrm{Na}$ intake in the United Kingdom (Ash and Wilbey, 2010), 9.2\% in France (Meneton et al., 2009), and 5\% in Australia (NHMRC, 2003). A simple reduction in $\mathrm{NaCl}$ without substitution with other salts adversely affected the cheese quality (Reddy and Marth, 1991). Substitution of $\mathrm{NaCl}$ with $\mathrm{KCl}$ was successfully used to preserve cheese quality. Numerous studies have been carried out to examine the effect of $\mathrm{NaCl}$ substitution with $\mathrm{KCl}$ on Halloumi cheese (Ayyash and Shah, 2010, 2011a; Ayyash et al., 2011), Nabulsi cheese (Ayyash and 
Shah, 2011b), Feta cheese (Katsiari et al., 1997), and Kefalograviera cheese (Katsiari et al., 2001; Katsiari et al., 1998). Chemical composition, proteolysis, microbial growth and texture profile are the major attributes that have been investigated in these studies. No significant differences have been reported in most measured variables between experimental cheeses as compared with controls (Katsiari et al., 1997, 1998). However, Ayyash and Shah $(2011 a, b)$ reported significant differences in small peptides [phosphotungstic acid (PTA)-soluble nitrogen (SN) and TCA-SN contents] between experimental cheeses made using partial substitution of $\mathrm{NaCl}$ with $\mathrm{KCl}$ compared with the control. Ayyash and Shah (2011b,d) found that $\mathrm{KCl}$ affected the bacterial enzyme activity produced during storage, leading to qualitative or quantitative variations in enzymes produced by starter culture or nonstarter culture bacteria; this, in turn, affected cheese proteolysis. In the current study, 2 probiotic bacteria Lactobacillus acidophilus 2401 and Lactobacillus casei 290 were added to Akawi cheese to investigate for the first time the effect of salt substitution on probiotic survival. The aims of this study were to investigate the effect of salt substitution with $\mathrm{KCl}$ on chemical composition, proteolysis and angiotensinconverting enzyme (ACE)-inhibitory activity, probiotic survival, texture profile, and sensory properties of probiotic Akawi cheese.

\section{MATERIALS AND METHODS}

\section{Bacteria Culture and Propagation}

Four bacterial strains: Streptococcus thermophilus MS (ST), Lactobacillus delbrueckii ssp. bulgaricus 11842 (LB), Lactobacillus acidophilus 2401 (LA), and Lactobacillus casei 290 (LC) were obtained from Victoria University Culture Collection (Werribee Campus, Victoria, Australia). Cultures were stored in de Man, Rogosa, and Sharpe (MRS) broth (Oxoid Ltd., West Heidelberg, Victoria, Australia) with $20 \%$ glycerol at $-80^{\circ} \mathrm{C}$. To activate the 4 cultures, a $100-\mu \mathrm{L}$ aliquot of each culture was individually transferred into MRS broth and incubated at $37^{\circ} \mathrm{C}$ for $24 \mathrm{~h}$. Weekly transfer was performed to maintain the bacterial activity. Before the experiments, 2 successive culture transfers were carried out in MRS broth and a third transfer was in sterilized reconstituted skim milk (RSM 13\%) and incubated at $37^{\circ} \mathrm{C}$ for $24 \mathrm{~h}$.

\section{Cheese Making}

Full-fat (3\%), homogenized, and pasteurized bovine milk was tempered at $40^{\circ} \mathrm{C}$. Streptococcus thermophilus MS, LB, LA, and LC were added at 1.5\% and mixed thoroughly for $2 \mathrm{~min}$. After $45 \mathrm{~min}$, the milk was coagulated using double-strength chymosin according to the manufacturer instructions (CHY-MAX; Chr. Hansen Pty Ltd., Bayswater, Victoria, Australia) for $40 \mathrm{~min}$. The curd was cut into $1-\mathrm{cm}^{3}$ cubes using cheese knives and settled for 10 min. Whey was drained and curd cubes were transferred to cheesecloth to further drain for $25 \mathrm{~min}$. Curd pieces were wrapped in cheesecloth in small portions $(\sim 150 \mathrm{~g})$ and pressed for $90 \mathrm{~min}$. Cheese pieces were placed in 4 brine solutions (at $10 \%$ ): $\mathrm{NaCl}$ only (A), $3 \mathrm{NaCl}: 1 \mathrm{KCl}(\mathrm{B}), 1 \mathrm{NaCl}: 1 \mathrm{KCl}(\mathrm{C})$, and 1 $\mathrm{NaCl}: 3 \mathrm{KCl}(\mathrm{D})$ and stored at $4^{\circ} \mathrm{C}$ for 1 mo. Samples were taken at $0,10,20$, and $30 \mathrm{~d}$ of storage. The experiment was repeated in triplicate.

\section{Chemical Composition}

The chemical composition was determined according to the Association of Official Analytical Chemists methods (AOAC, 1995); moisture content was determined by the oven-drying method at $102^{\circ} \mathrm{C}$, fat by the Babcock method, protein by the Kjeldahl method, and ash by the muffle furnace method. For $\mathrm{pH}$ measurement, $20 \mathrm{~g}$ of grated cheese was macerated in $20 \mathrm{~mL}$ of distilled water, and the $\mathrm{pH}$ of the resultant slurry was measured using a calibrated digital $\mathrm{pH}$ meter (MeterLab; Pacific Laboratory Products Australia Pty Ltd., Melbourne, Victoria, Australia).

\section{Survival of Bacterial in Akawi Cheese}

The 4 bacteria mentioned previously were enumerated according to Ong et al. (2006) and the International Organization for Standardization (ISO/IDF, 2002). Grated cheese (25 g) was blended into $225 \mathrm{~mL}$ of peptone water $(0.1 \%)$. Serial dilutions were made and each type of bacteria was enumerated on appropriate agar. Streptococcus thermophilus MS were counted using M17 (Oxoid Ltd.) and aerobically incubated at $37^{\circ} \mathrm{C}$ for 24 h. Lactobacillus delbrueckii ssp. bulgaricus 11842 was enumerated using pH-modified (pH 4.5) MRS agar (Merck Pty Ltd., Victoria, Australia) and incubated anaerobically at $45^{\circ} \mathrm{C}$ for $72 \mathrm{~h}$. de Man, Rogosa, and Sharpe agar supplemented with sorbitol (Merck Pty Ltd.) was used to enumerate LA. The supplemented MRS-sorbitol agar was prepared by adding $10 \mathrm{~mL}$ of membrane-filtered sterile $10 \%$ solutions (wt/vol) of sorbitol to $90 \mathrm{~mL}$ of molten MRS agar just before pouring. Plates were anaerobically incubated at $37^{\circ} \mathrm{C}$ for $72 \mathrm{~h}$. de Man, Rogosa, and Sharpe-vancomycin (MRS-V) agar was used for the selective enumeration of LC. The MRS-V agar was prepared by adding $2 \mathrm{~mL}$ of $0.5 \mathrm{mg} / \mathrm{mL}$ of vancomycin (Sigma-Aldrich, St. Louis, MO) solution to $1 \mathrm{~L}$ 
of molten MRS agar just before pouring to obtain a 1-mg/L final concentration. The plates were anaerobically incubated at $37^{\circ} \mathrm{C}$ for $72 \mathrm{~h}$. The anaerobic condition for all bacteria was achieved using anaerobic jars and Anaerocult C (Merck Pty Ltd.) to generate an anaerobic atmosphere in anaerobic jars.

\section{Organic Acids Analysis}

Lactic, citric, and acetic acids were determined using HPLC according to Ayyash and Shah (2010), with some modifications. A 5-mL aliquot of water-soluble extract (WSE) was freeze dried. The freeze-dried powder was dissolved in $3 \mathrm{~mL}$ of $0.009 \mathrm{~N}$ sulfuric acid (Merck Pty Ltd.) and then centrifuged at 3,000 $\times g$ for $15 \mathrm{~min}$. The supernatant was filtered using a 0.45 $\mu \mathrm{m}$ membrane filter (Millex; Millipore Corp., Bedford, MA) and $20 \mu \mathrm{L}$ was injected into the HPLC system. The HPLC system consisted of a Varian 9012 solvent delivery system, a Varian 9100 autosampler, a Varian 9050 variable wavelength UV-visible (UV-Vis) tunable absorbance detector and a 730 data module (Varian Inc., Palo Alto, CA). An Aminex HPX-87H column $(300 \times 7.8 \mathrm{~mm}$; Bio-Rad Laboratories Inc., Richmond, CA), was used. Sulfuric acid (0.009 N), filtered through a $0.45-\mu \mathrm{m}$ membrane filter (Millipore Corp.) was used as a mobile phase at a flow rate of $0.6 \mathrm{~mL} / \mathrm{min}$. The detection device was a UV-Vis detector set at $220 \mathrm{~nm}$ with running time of $15 \mathrm{~min}$. Organic acid concentration was calculated using an external standard curve.

\section{Assessment of Proteolysis}

The WSE of the cheese samples were prepared according to Kuchroo and Fox (1982). The nitrogen in the extract was estimated by the Kjeldahl method (AOAC, 1995). Twelve percent TCA-SN and 5\% PTA-SN were determined according to Ayyash and Shah (2011a). Trichloroacetic acid SN was analyzed as follows: a 5-mL sample of WSE was mixed with $24 \%$ TCA (Sigma-Aldrich) and kept overnight at room temperature. The mixture was centrifuged at $3,000 \times g$ for $20 \mathrm{~min}$ and $9 \mathrm{~mL}$ of the supernatant was analyzed for SN by the Kjeldahl method (AOAC, 1995). The extent of secondary proteolysis (PTA-SN) was assayed similarly to TCA-SN using $9 \mathrm{~mL}$ of filtrate obtained after precipitation of filtered WSE of cheese with $10 \%$ PTA (Sigma-Aldrich).

\section{Peptide Profile by Reverse-Phase HPLC}

The peptide profile of Akawi cheese during the storage period was examined by HPLC according to Ayyash and Shah (2011a). Five milliliters of WSE was freeze dried and then mixed with $3 \mathrm{~mL}$ of solvent
A containing $0.1 \%$ trifluoroacetic acid (TFA; SigmaAldrich), centrifuged $(12,000 \times g$ for $10 \mathrm{~min})$ using a benchtop centrifuge (Sorvall RT7; Sorvall, Newtown, $\mathrm{CT}$ ), and filtered through a $0.45-\mu \mathrm{m}$ filter (Millipore Corp.). The reverse-phase HPLC analysis was carried out using HPLC consisting of a Varian 9012 solvent delivery system, a Varian 9100 autosampler, a Varian 9050 variable wavelength $\mathrm{UV}$-Vis tunable absorbance detector, and a 730 data module. A sample size of 50 $\mu \mathrm{L}$ was injected into the $\mathrm{C} 18$ reverse-phase column (250-mm length $\times$ 4.6-mm diameter, 5 - $\mu \mathrm{m}$ diameter of the column particles inside; Grace Vydac, Hesperia, CA $)$ with a guard column $(10 \times 12 \mathrm{~mm}$; Grace Vydac Separations Inc., Hesperia, CA). The separation was conducted at room temperature $\left(\sim 22^{\circ} \mathrm{C}\right)$ at a flow rate of $0.75 \mathrm{~mL} / \mathrm{min}$. Eluent B was $60 \%$ acetonitrile (Merck Pty Ltd.) containing $0.05 \%$ TFA. A linear gradient was applied from 0 to $80 \%$ eluent B over $100 \mathrm{~min}$, followed by 10 min to equilibrate the column with $100 \%$ solvent A. The detection device was a UV-Vis detector set at $215 \mathrm{~nm}$ and reverse-phase HPLC chromatograms were visually analyzed.

\section{Measurement of Total Free AA}

Total free AA (TFAA) concentrations of water-soluble nitrogen of Akawi cheese samples were measured using the Cd-ninhydrin method according to Folkertsma and Fox (1992) and WSE, prepared as previously described, was used in analysis. An aliquot (100 $\mu \mathrm{L}$ ) was placed in a glass tube and diluted with $1 \mathrm{~mL}$ of Milli-Q water (Millipore Corp.). Two milliliters of Cd-ninhydrin reagent $[0.8 \mathrm{~g}$ of ninhydrin was dissolved in a mixture of $10 \mathrm{~mL}$ of glacial acetic acid (100\%) and $80 \mathrm{~mL}$ of ethanol (99.5\%), followed by dissolving $1 \mathrm{~g}$ of $\mathrm{CdCl}_{2}$ in $1 \mathrm{~mL}$ of Milli-Q water] was added. The mixture was heated at $84^{\circ} \mathrm{C}$ for $5 \mathrm{~min}$ and then cooled at room temperature then absorbance at 507 nm was measured using a UV-VIS spectrophotometer [UV-1800; Shimadzu Scientific Instruments (Oceania) Pty Ltd., Rydalmere, New South Wales, Australia]. All chemicals were purchased from Sigma-Aldrich and analyses were carried out in duplicate.

\section{Proteolytic Activity by o-Phthalaldehyde}

Proteolytic activity of Akawi cheese samples was determined according to Church et al. (1983). Briefly, $50 \mu \mathrm{L}$ of WSE was placed into a 1.5-mL cuvette and mixed with $1 \mathrm{~mL}$ of $o$-phthalaldehyde (OPA) reagent prepared in a $50-\mathrm{mL}$ volumetric flask as follows: $25 \mathrm{~mL}$ of $100 \mathrm{~m} M$ disodium tetraborate (Merck Pty Ltd.), 2.5 $\mathrm{mL}$ of $20 \%$ (wt/wt) SDS (Merck Pty Ltd.), $40 \mathrm{mg}$ of OPA dissolved in $1 \mathrm{~mL}$ of methanol (Merck Pty Ltd.), 
and $100 \mu \mathrm{L}$ of $\beta$-mercaptoethanol (Sigma-Aldrich). The volume was completed with Milli-Q water. The cuvette was inverted twice and the incubated for $2 \mathrm{~min}$ at room temperature. The absorbance was measured at $340 \mathrm{~nm}$ using a UV-VIS spectrophotometer [Shimadzu Scientific Instruments (Oceania) Pty Ltd.] in duplicate.

\section{ACE-Inhibitory Activity in WSE}

Angiotensin-converting enzyme-inhibitory activity was measured according to Ayyash and Shah (2011d) using HPLC. Five milliliters of WSE was freeze dried and then dissolved in $1 \mathrm{~mL}$ of Tris buffer $(50 \mathrm{mM}$, pH 8.3) containing $300 \mathrm{~m} M \mathrm{NaCl}$. The ACE enzyme (from rabbit lung) and hippuryl-histidyl-leucine (HHL) were purchased from Sigma-Aldrich and prepared in Tris buffer. The assay consisted of $50 \mu \mathrm{L}$ of $3.0 \mathrm{mM}$ HHL, $50 \mu \mathrm{L}$ of $1.25-\mathrm{mU} / \mathrm{mL}$ ACE enzyme, and $50 \mu \mathrm{L}$ of dissolved WSE sample. The mixture was placed in a glass tube and then incubated for $30 \mathrm{~min}$ at $37^{\circ} \mathrm{C}$ in a water bath without mixing and then for an additional $30 \mathrm{~min}$ after mixing. Glacial acetic acid $(150 \mu \mathrm{L})$ was added to stop ACE enzyme activity. The mixture was kept at $-20^{\circ} \mathrm{C}$ to be analyzed using HPLC. The resulting hippuric acid from the previous reaction was determined using HPLC. An external standard curve was prepared to quantify the hippuric acid in assay samples. An aliquot $(20 \mu \mathrm{L})$ of the mixture was injected into the HPLC system consisting of a Varian 9012 solvent delivery system, a Varian 9100 autosampler, a Varian 9050 variable wavelength UV-Vis tunable absorbance detector, and a 730 data module. The system was fitted with a reverse-phase column (Luna C18, 250-mm length $\times$ 4.6-mm diameter, $5-\mu \mathrm{m}$ diameter of the HPLC column particles inside; Phenomenex Australia Pty Ltd., New South Wales, Australia) with a guard column (C18 $4 \times$ $3.0 \mathrm{~mm}$; Phenomenex Australia Pty Ltd.). The separation was conducted at room temperature $\left(\sim 22^{\circ} \mathrm{C}\right)$ at a flow rate of $0.8 \mathrm{~mL} / \mathrm{min}$. The mobile phase was an isocratic system consisting of $12.5 \%$ ( vol/vol) acetonitrile (Merck Pty Ltd.) in Milli-Q water, and the $\mathrm{pH}$ was adjusted to $\mathrm{pH} 3.0$ using glacial acetic acid (Merck Pty Ltd.). The detection device was a UV-Vis detector set at $228 \mathrm{~nm}$. The control reaction mixture contained $50 \mu \mathrm{L}$ of buffer instead of the assay sample; the control was expected to liberate the maximum amount of hippuric acid from the substrate due to uninhibited ACE activity. The percent inhibition of enzyme activity was calculated as follows:

Inhibition percentage

$=\frac{\text { hippuric acid }(\text { control })-\text { hippuric acid (sample) }}{\text { hippuric acid }(\text { control })} \times 100$.

\section{Determination of Total $\mathrm{Ca}, \mathrm{P}, \mathrm{Na}$, and $\mathrm{K}$ Contents by Multitype Inductively Coupled Plasma Atomic Emission Spectrometry}

Calcium, $\mathrm{K}, \mathrm{Na}$, and $\mathrm{P}$ contents in Akawi cheese samples were determined by multitype inductively coupled plasma atomic emission (ICPE) spectrometry [ICPE-9000; Shimadzu Scientific Instruments (Oceania) Pty Ltd.] according to Ayyash and Shah (2011b) with some modifications. Grated cheese (5 g) was digested in a mixture of $\mathrm{HNO}_{3}$ and $\mathrm{HClO}_{4}$ (5:1; Merck Pty Ltd.) on a hot plate until the mixture was clear. The original sample was diluted 1 to 10 in Milli-Q water. The diluted samples were filtered with a $0.45-\mu \mathrm{m}$ filter and analyzed using ICPE-9000 [Shimadzu Scientific Instruments (Oceania) Pty Ltd.]. All samples were diluted 100 times and then filtered using $0.45 \mu \mathrm{m}$ (Millipore Corp.) before directly injecting into the ICPE-9000 spectrometer. The ICPE-9000 spectrometer consisted of an ASC-6100 autosampler, a hydride generator HVG-ICP, a hydrofluoric acid sample injection system (HFS-2), a low-temperature thermostatic chamber (NCB-1200), and a software package (ICPE-9000). Calcium, K, Na, and $\mathrm{P}$ concentrations were calculated in samples using an external standard curve consisting of the 4 elements, prepared at 1, 10, 20,30, and $40 \mathrm{mg} / \mathrm{kg}$.

\section{Soluble $\mathrm{Ca}, \mathrm{P}, \mathrm{Na}$, and $\mathrm{K}$}

The soluble $\mathrm{Ca}$, expressed as percentage of total $\mathrm{Ca}$ in Akawi cheese, was analyzed according to Ayyash and Shah (2011c), with some modifications. Briefly, grated cheese $(10 \mathrm{~g})$ was taken from the shredded cheese lot and homogenized with $90 \mathrm{~mL}$ of Milli-Q water (Millipore Corp.) using an Ultra-Turrax homogenizer (Janke \& Kunkel GmbH \& Co. KG, Staufen im Breisgau, Germany) at 10,000 rpm for $3 \mathrm{~min}$. The cheese slurry was centrifuged at $4,000 \times g$ for $20 \mathrm{~min}$ and then the supernatant was filtrated using Whatman \#41 filter paper (Whatman International Ltd., Maidstone, UK). The filtrate was filtered with a $0.45-\mu \mathrm{m}$ filter (Millex; Millipore Corp.) and then soluble $\mathrm{Ca}$ and $\mathrm{P}$ were analyzed using the ICP method, which was previously mentioned. The $\mathrm{Ca}$ and $\mathrm{P}$ percentage was calculated as follows:

$$
\begin{aligned}
& \text { Percentage of soluble Ca, P, Na, and K } \\
& =\frac{\text { soluble } \mathrm{Ca}, \mathrm{P}, \mathrm{Na} \text {, and } \mathrm{K}(\mathrm{mg} / 100 \mathrm{~g})}{\text { total } \mathrm{Ca}, \mathrm{P}, \mathrm{Na} \text {, and } \mathrm{K}(\mathrm{mg} / 100 \mathrm{~g})} \times 100 \text {. }
\end{aligned}
$$

\section{Texture Profile Analysis}

The texture profile (hardness, cohesiveness, adhesiveness, and gumminess) was analyzed according to Ayyash 
Table 1. The description of sensory evaluation attributes ${ }^{1}$

\begin{tabular}{lll}
\hline Attribute & Definition & Reference \\
\hline Creaminess & Flavor associated with fresh milk, creamy product, condensed milk & Ultra-high-temperature (UHT) \\
& pasteurized cream with $35 \%$ fat \\
Bitterness & Chemical-like, aspirin, taste sensation of caffeine & Caffeine (0.06\% in water) \\
Saltiness & Fundamental taste sensation of which sodium chloride is typical & Sodium chloride (1\% in water) \\
Sour-acid & Fundamental taste sensation of lactic or citric acid & Citric acid (0.08\% in water) and \\
Vinegar & Flavor associated with vinegar & acetic acid $(0.08 \%$ in water) \\
\hline
\end{tabular}

${ }^{1}$ Sensory attribute definitions and references were described according to Ong (2007) and Delahunty and Drake (2004).

et al. (2011). Cylinders of $25 \times 20-\mathrm{mm}$ (diameter $\times$ height) cheeses were cut from Akawi cheese blocks at the center. Specimens were kept in a refrigerator at $4^{\circ} \mathrm{C}$ overnight in sealed plastic containers and then texture profiles were determined. Hardness, cohesiveness, adhesiveness, and gumminess were measured using an Instron universal testing machine (model 5564; Instron Ltd., London, UK) based on the principles described by Pons and Fiszman (1996). The samples were compressed to $50 \%$ of their heights using a $100-\mathrm{N}$ load cell with a flat plunger and the crosshead movement was adjusted to $50 \mathrm{~mm} / \mathrm{min}$. Two cycle compressions were carried out and the data were collected using Merlin software (Woodville, South Australia). Analyses were performed in duplicate.

\section{Sensory Properties}

Ten panelists were recruited for assessing sensory attributes. The panelists were familiar with basic sensory evaluation techniques for cheeses and were further trained for their ability to detect creaminess, bitterness, saltiness, sour-acid, and vinegar taste. Prior to sensory evaluation, they also participated in a briefing session. All panelists signed a Victoria University human subject's consent form. Sensory evaluation was conducted for Akawi cheeses at d 10, 20, and 30 of storage. Cheese samples were removed from the refrigerator, tempered at room temperature $\left(20^{\circ} \mathrm{C}\right)$ for $1 \mathrm{~h}$ and cut into pieces and placed on white plates coded with random numbers. The panelists evaluated 12 cheese samples and water was provided to cheese panelists between each sample. The panelists scored the attributes using a 10-point scale as follows: creaminess: $1=$ absent, 10 $=$ extremely creamy; bitterness: $1=$ absent, $10=$ extremely bitter; saltiness: $1=$ absent, $10=$ extremely salty; sour-acid: $1=$ not acidic, $10=$ extremely acidic; and vinegar: $1=$ not detected, $10=$ high intensity. The definitions of sensory attributes and references are presented in Table 1. Panelists were trained for their ability to rank products with different concentrations of lactic acid, acetic acid, sodium chloride, and caffeine from lowest intensity to highest intensity in water and in cream cheese. Tests were repeated until the panelists were able to rank different intensities of lactic acid, acetic acid, sodium chloride, and caffeine in both water and cream cheese (Ong, 2007).

\section{Statistical Analysis}

One-way ANOVA was performed to investigate significant differences $(P<0.05)$ between experimental cheeses at the same storage period. The Fisher least significant difference (LSD) test was carried out to examine differences between means of experimental cheeses at the same storage period. The significance of storage period was examined for the same salt treatment using the LSD test.

\section{RESULTS AND DISCUSSION}

\section{Chemical Composition}

Moisture, protein, fat, and ash contents in addition to $\mathrm{pH}$ values of 4 experimental Akawi cheeses during $30 \mathrm{~d}$ of storage are presented in Table 2. In general, no significant differences $(P>0.05)$ were observed in moisture, protein, fat, and ash contents among the experimental Akawi cheeses at same storage period. These results are in accordance with those of Ayyash and Shah $(2010,2011 b)$ who reported similar results in Halloumi and Nabulsi cheeses. As seen in Table 2, an occasional significant difference $(P<0.05)$ occurred between experimental cheeses in moisture content at $\mathrm{d}$ 20 , protein and ash contents at $\mathrm{d} 30$, and fat content at $\mathrm{d} 0$ and 20. This may be attributed to differences in cheese loaves, but not due to salt treatment. Similar results have been reported by Ayyash and Shah (2011b). The $\mathrm{pH}$ values significantly $(P<0.05)$ differed among Akawi cheeses for the same salt treatment. After d 10 of storage, $\mathrm{pH}$ values of Akawi cheese in treatments $\mathrm{C}$ and $\mathrm{D}$ were higher compared with treatments $\mathrm{A}$ and $\mathrm{B}$. This suggested that when the substitution level with $\mathrm{KCl}$ increased $(\mathrm{C}=50 \%$ and $\mathrm{D}=75 \%)$, the $\mathrm{pH}$ values increased. This result is in agreement with Ayyash and Shah (2011b) and Katsiari et al. (1997) who reported 
Table 2. Moisture, protein, fat, and ash contents and $\mathrm{pH}$ values (mean values $\pm \mathrm{SE}$ of 3 trials) of Akawi cheeses kept in 4 levels of NaCl and $\mathrm{KCl}$ during storage for $30 \mathrm{~d}$ at $4^{\circ} \mathrm{C}$

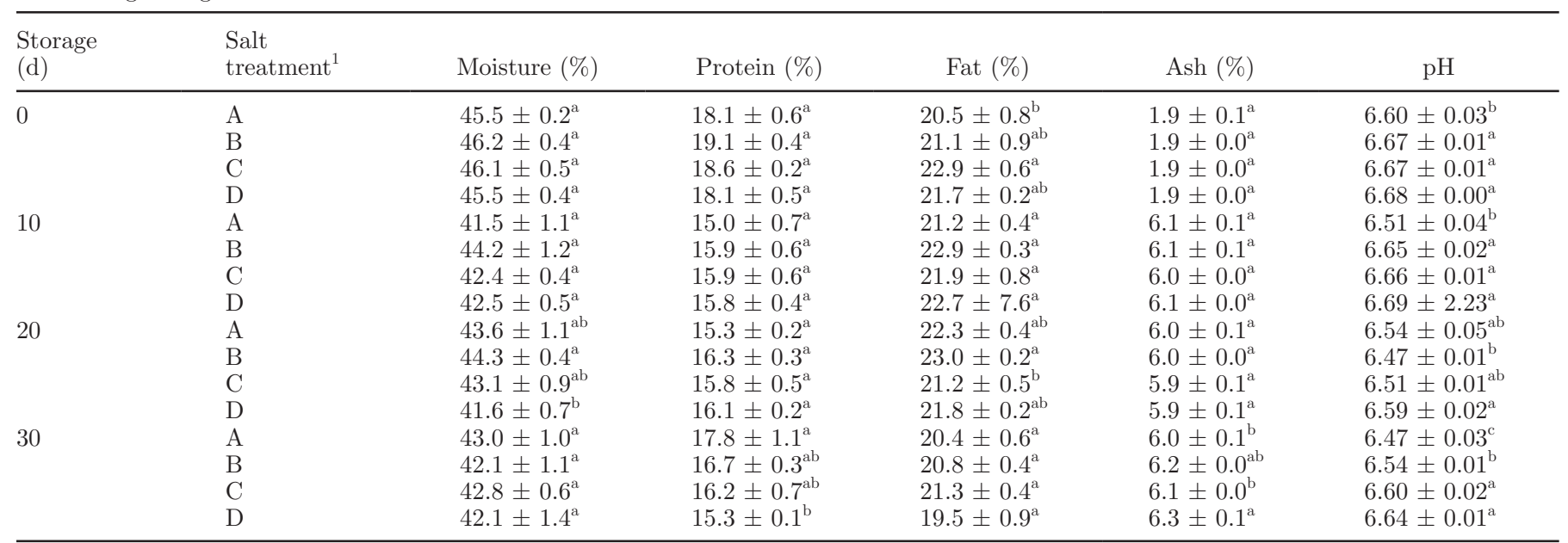

\footnotetext{
${ }^{a-c}$ Means within a column and at the same storage time with the same superscript letter did not differ significantly $(P>0.05)$.
}

${ }^{1}$ Salt treatment: $\mathrm{A}=\mathrm{NaCl}$ only (control); $\mathrm{B}=3 \mathrm{NaCl}: 1 \mathrm{KCl}$ (wt/wt); C = $1 \mathrm{NaCl}: 1 \mathrm{KCl}$ (wt/wt); D = $1 \mathrm{NaCl}: 3 \mathrm{KCl}$ (wt/wt).

similar results. This $\mathrm{pH}$ trend may be due to the higher $\mathrm{pH}$ of the $\mathrm{KCl}$ solution by about 0.3 compared with $\mathrm{NaCl}$. Analysis of variance showed that moisture and protein contents significantly $(P<0.05)$ decreased and ash content increased $(P<0.05)$ during storage at the same salt treatment. This is due to migration of moisture from the cheese loaf toward the brine solution, which decreased $(P<0.05)$ the moisture content during storage. Also, the migration of salt from the brine solution toward the cheese loaf increased $(P<$ $0.05)$ the ash content during the storage period for the same salt treatment. These results agree with those of
Ayyash and Shah (2010) who reported similar results in Halloumi cheese.

\section{Assessment of Proteolysis}

Five measured indicators of proteolysis: water-soluble nitrogen, TCA-SN, PTA-SN, OPA, and TFAA are presented in Table 3. No significant differences were found in TCA-SN and TFAA between experimental cheeses at the same storage period. Starting from d 10 to the end of storage, significant $(P<0.05)$ differences were observed in water-soluble nitrogen and PTA-SN among

Table 3. Water-soluble nitrogen (WSN), TCA, phosphotungstic acid (PTA), o-phthalaldehyde (OPA), and total free AA (TFAA) contents (mean values $\pm \mathrm{SE}$ of 3 trials) of Akawi cheeses kept in 4 levels of $\mathrm{NaCl}$ and $\mathrm{KCl}$ during storage for $30 \mathrm{~d}$ at $4^{\circ} \mathrm{C}$

\begin{tabular}{|c|c|c|c|c|c|c|}
\hline $\begin{array}{l}\text { Storage } \\
\text { (d) }\end{array}$ & $\begin{array}{l}\text { Salt } \\
\text { treatment }^{1}\end{array}$ & WSN & TCA & PTA & OPA & TFAA \\
\hline \multirow[t]{4}{*}{0} & $\mathrm{~A}$ & $3.29 \pm 0.15^{\mathrm{a}}$ & $1.02 \pm 0.01^{\mathrm{a}}$ & $0.19 \pm 0.01^{\mathrm{a}}$ & $0.51 \pm 0.10^{\mathrm{a}}$ & $0.22 \pm 0.03^{\mathrm{ab}}$ \\
\hline & B & $3.28 \pm 0.11^{\mathrm{a}}$ & $0.93 \pm 0.05^{\mathrm{a}}$ & $0.18 \pm 0.01^{\mathrm{a}}$ & $0.42 \pm 0.09^{\mathrm{a}}$ & $0.19 \pm 0.01^{\mathrm{ab}}$ \\
\hline & $\mathrm{C}$ & $3.28 \pm 0.09^{\mathrm{a}}$ & $1.00 \pm 0.06^{\mathrm{a}}$ & $0.19 \pm 0.01^{\mathrm{a}}$ & $0.50 \pm 0.04^{\mathrm{a}}$ & $0.26 \pm 0.01^{\mathrm{a}}$ \\
\hline & $\mathrm{D}$ & $3.63 \pm 0.17^{\mathrm{a}}$ & $1.03 \pm 0.07^{\mathrm{a}}$ & $0.20 \pm 0.01^{\mathrm{a}}$ & $0.46 \pm 0.12^{\mathrm{a}}$ & $0.16 \pm 0.04^{\mathrm{b}}$ \\
\hline \multirow[t]{4}{*}{10} & $\mathrm{~A}$ & $5.60 \pm 0.43^{\mathrm{ab}}$ & $1.31 \pm 0.29^{\mathrm{a}}$ & $0.60 \pm 0.04^{\mathrm{a}}$ & $0.25 \pm 0.02^{\mathrm{a}}$ & $0.14 \pm 0.01^{\mathrm{a}}$ \\
\hline & B & $5.21 \pm 0.27^{\mathrm{ab}}$ & $1.26 \pm 0.17^{\mathrm{a}}$ & $0.42 \pm 0.06^{\mathrm{b}}$ & $0.33 \pm 0.06^{\mathrm{a}}$ & $0.20 \pm 0.06^{\mathrm{a}}$ \\
\hline & $\mathrm{C}$ & $4.59 \pm 0.15^{\mathrm{b}}$ & $1.10 \pm 0.02^{\mathrm{a}}$ & $0.45 \pm 0.06^{\mathrm{ab}}$ & $0.38 \pm 0.15^{\mathrm{a}}$ & $0.20 \pm 0.03^{\mathrm{a}}$ \\
\hline & $\mathrm{D}$ & $5.94 \pm 0.28^{\mathrm{a}}$ & $1.22 \pm 0.11^{\mathrm{a}}$ & $0.40 \pm 0.01^{\mathrm{b}}$ & $0.60 \pm 0.19^{\mathrm{a}}$ & $0.14 \pm 0.02^{\mathrm{a}}$ \\
\hline \multirow[t]{4}{*}{20} & $\mathrm{~A}$ & $5.56 \pm 0.40^{\mathrm{a}}$ & $1.24 \pm 0.07^{\mathrm{a}}$ & $0.69 \pm 0.13^{\mathrm{a}}$ & $0.30 \pm 0.02^{\mathrm{b}}$ & $0.16 \pm 0.04^{\mathrm{a}}$ \\
\hline & B & $4.66 \pm 0.04^{\mathrm{b}}$ & $1.22 \pm 0.07^{\mathrm{a}}$ & $0.46 \pm 0.01^{\mathrm{b}}$ & $0.36 \pm 0.05^{\mathrm{b}}$ & $0.11 \pm 0.01^{\mathrm{a}}$ \\
\hline & $\mathrm{C}$ & $4.69 \pm 0.24^{\mathrm{b}}$ & $1.12 \pm 0.08^{\mathrm{a}}$ & $0.39 \pm 0.02^{\mathrm{b}}$ & $0.38 \pm 0.04^{\mathrm{ab}}$ & $0.19 \pm 0.06^{\mathrm{a}}$ \\
\hline & $\mathrm{D}$ & $4.61 \pm 0.04^{\mathrm{b}}$ & $1.24 \pm 0.19^{\mathrm{a}}$ & $0.41 \pm 0.02^{\mathrm{b}}$ & $0.51 \pm 0.05^{\mathrm{a}}$ & $0.16 \pm 0.06^{\mathrm{a}}$ \\
\hline \multirow[t]{4}{*}{30} & $\mathrm{~A}$ & $4.77 \pm 0.39^{\mathrm{ab}}$ & $1.53 \pm 0.31^{\mathrm{a}}$ & $0.50 \pm 0.06^{\mathrm{a}}$ & $0.36 \pm 0.03^{\mathrm{b}}$ & $0.11 \pm 0.01^{\mathrm{a}}$ \\
\hline & B & $4.94 \pm 0.18^{\mathrm{ab}}$ & $1.60 \pm 0.14^{\mathrm{a}}$ & $0.37 \pm 0.02^{\mathrm{b}}$ & $0.26 \pm 0.04^{\mathrm{b}}$ & $0.09 \pm 0.01^{\mathrm{a}}$ \\
\hline & $\mathrm{C}$ & $4.39 \pm 0.07^{\mathrm{b}}$ & $1.51 \pm 0.09^{\mathrm{a}}$ & $0.42 \pm 0.04^{\mathrm{ab}}$ & $0.30 \pm 0.01^{\mathrm{b}}$ & $0.12 \pm 0.02^{\mathrm{a}}$ \\
\hline & $\mathrm{D}$ & $5.20 \pm 0.12^{\mathrm{a}}$ & $1.66 \pm 0.07^{\mathrm{a}}$ & $0.42 \pm 0.01^{\mathrm{ab}}$ & $0.75 \pm 0.03^{\mathrm{a}}$ & $0.14 \pm 0.04^{\mathrm{a}}$ \\
\hline
\end{tabular}

\footnotetext{
${ }^{\mathrm{a}, \mathrm{b}}$ Means within a column and at the same storage time with the same superscript letter did not differ significantly $(P>0.05)$.

${ }^{1}$ Salt treatment: $\mathrm{A}=\mathrm{NaCl}$ only (control); $\mathrm{B}=3 \mathrm{NaCl}: 1 \mathrm{KCl}$ (wt/wt); C $=1 \mathrm{NaCl}: 1 \mathrm{KCl}$ (wt/wt); $\mathrm{D}=1 \mathrm{NaCl}: 3 \mathrm{KCl}$ (wt/wt).
} 

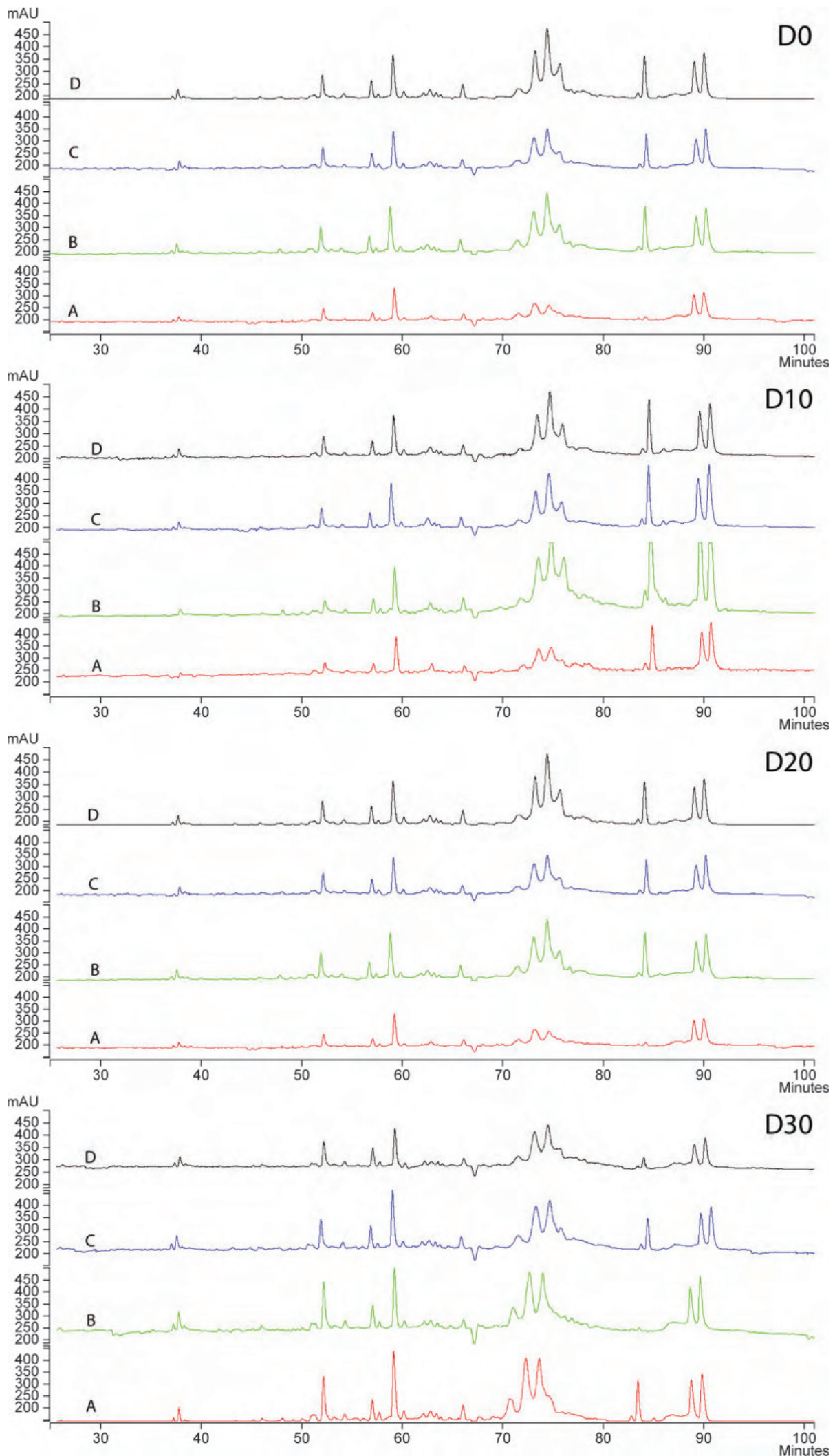

Figure 1. Reversed-phase HPLC profiles of water-soluble extract (WSE) of Akawi cheese at d 0, 10, 20, and 30 (D0, D10, D20, and D30, respectively), which was salted with $\mathrm{A}$ (red) $=\mathrm{NaCl}$ only (control); $\mathrm{B}$ (green) $=3 \mathrm{NaCl}: 1 \mathrm{KCl}$ (wt/wt); $\mathrm{C}$ (blue) $=1 \mathrm{NaCl}: 1 \mathrm{KCl}$ (wt/wt); or $\mathrm{D}($ black $)=1 \mathrm{NaCl}: 3 \mathrm{KCl}(\mathrm{wt} / \mathrm{wt})$ and stored at $4^{\circ} \mathrm{C}$. Color version available in the online PDF. 


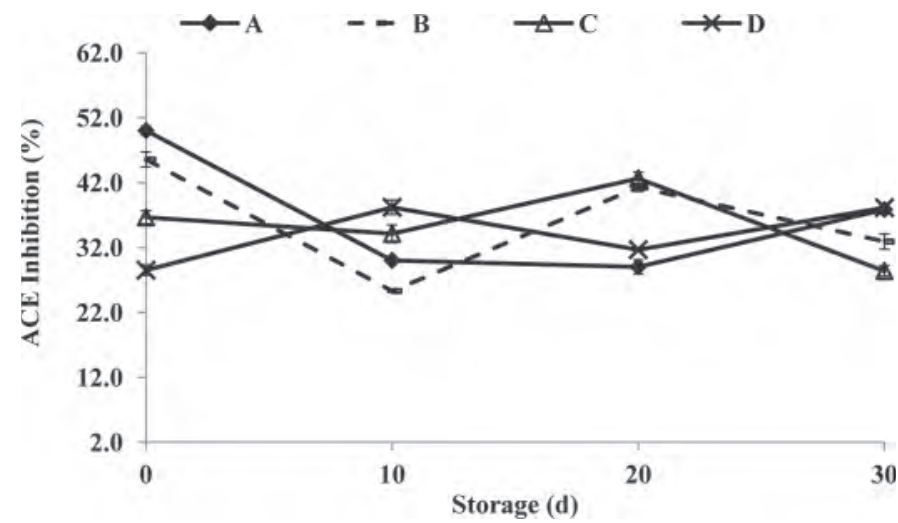

Figure 2. Angiotensin-converting enzyme (ACE)-inhibitory percentage of water-soluble extract (WSE) of Akawi cheese salted with 4 levels of an $\mathrm{NaCl} / \mathrm{KCl}$ mixture, $\mathrm{A}=\mathrm{NaCl}$ only (control); $\mathrm{B}=3$ $\mathrm{NaCl}: 1 \mathrm{KCl}$ (wt/wt); C = $1 \mathrm{NaCl}: 1 \mathrm{KCl}$ (wt/wt); D = $1 \mathrm{NaCl}: 3 \mathrm{KCl}$ (wt/wt), during storage at $4^{\circ} \mathrm{C}$ for $30 \mathrm{~d}$.

experimental cheeses at the same storage period. However, OPA differed significantly $(P<0.05)$ between Akawi cheeses starting from d 20 of storage (Table 3). As seen from Table 2, PTA-SN content in Akawi cheese of treatment A (control) was higher $(P<0.05)$ compared with other treatments $(\mathrm{B}, \mathrm{C}$, and $\mathrm{D})$ starting at d 10 until the end of the storage period. However, the OPA content in Akawi cheese of treatment D was higher $(P<0.05)$ compared with other treatments $(\mathrm{A}$, $\mathrm{B}$, and $\mathrm{C}$ ). This trend may be attributed to the activity of proteolytic enzymes produced by lactic acid bacteria and probiotic bacteria, which, in turn, may be affected by the presence or absence of KCL. This supported the hypothesis that was proposed by Ayyash and Shah (2011b,d) and Armenteros et al. (2009) who reported that the presence of $\mathrm{KCl}$ inactivated or activated particular proteolytic enzymes. Water-soluble nitrogen, TCA-SN, and PTA-SN showed a significant $(P<0.05)$ increase during storage for the same salt treatment.

\section{Peptides Profiles and ACE-Inhibitory Activity}

The peptide profile chromatograms of the experimental Akawi cheeses are shown in Figure 1. The hydrophobic peptides were dominant in all peptide profiles of experimental cheeses (Figure 1). At the same storage period, the chromatograms of treatments $\mathrm{B}, \mathrm{C}$, and $\mathrm{D}$ were similar compared with the control (treatment A). As can be noticed, generally, the number of hydrophobic peptides in all experimental cheeses increased during the storage period (Figure 1). The ACE-inhibitory activity of Akawi cheeses during the storage period is shown in Figure 2. In general, no significant $(P>0.05)$ difference existed in ACE-inhibitory activity between experimental Akawi cheeses at the same storage period. This result is in contrast to the result of Ayyash and Shah (2011d) who reported a significant difference in ACE-inhibitory activity among experimental lowmoisture Mozzarella cheeses. This variation may be attributed to the difference between cheese type and manufacturing steps. Analysis of variance showed that the ACE-inhibitory activity increased $(P>0.05)$ during the storage period for the same salt treatment.

\section{The Survival of Bacteria}

The starter culture bacterial growth (ST and LB) and that of the 2 probiotic bacteria (LC and LA) are

Table 4. Streptococcus thermophilus, Lactobacillus delbrueckii ssp. bulgaricus, Lactobacillus casei, and Lactobacillus acidophilus growth (cfu/g; mean values $\pm \mathrm{SE}$ of 3 trials) in Akawi cheeses kept in 4 levels of $\mathrm{NaCl}$ and $\mathrm{KCl}$ during storage for $30 \mathrm{~d}$ at $4^{\circ} \mathrm{C}$

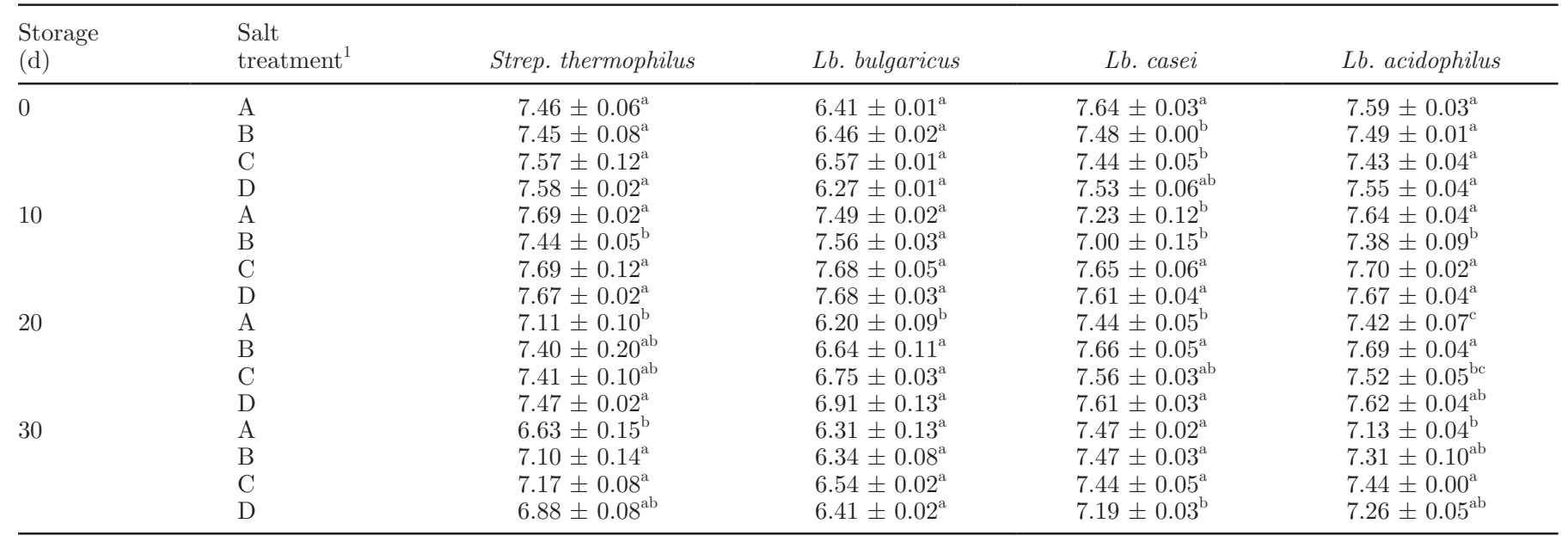

\footnotetext{
${ }^{\mathrm{a}-\mathrm{c}}$ Means within a column and at the same storage time with the same superscript letter did not differ significantly $(P>0.05)$.

${ }^{1}$ Salt treatment: $\mathrm{A}=\mathrm{NaCl}$ only (control); $\mathrm{B}=3 \mathrm{NaCl}: 1 \mathrm{KCl}$ (wt/wt); C = $1 \mathrm{NaCl}: 1 \mathrm{KCl}$ (wt/wt); D = $1 \mathrm{NaCl}: 3 \mathrm{KCl}$ (wt/wt).
} 


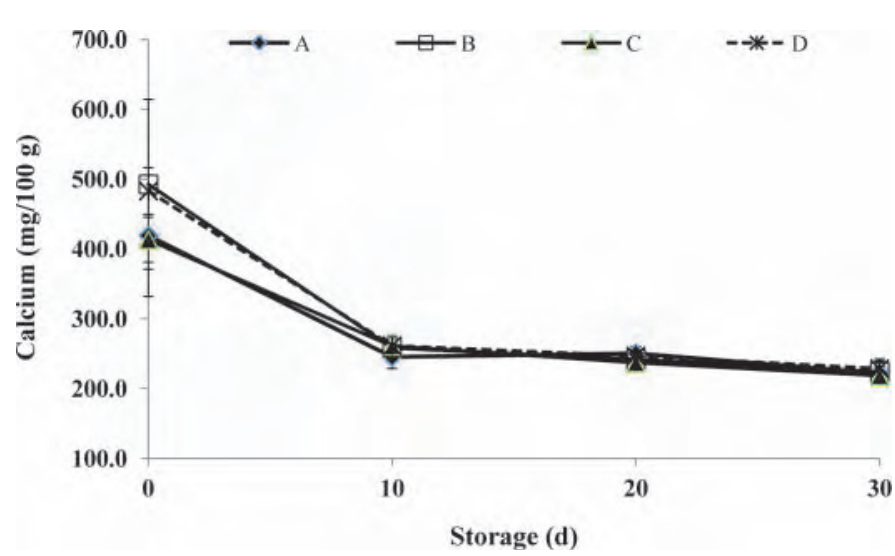

Figure 3. Calcium contents of Akawi cheeses stored in 4 levels of $\mathrm{NaCl}$ and $\mathrm{KCl}, \mathrm{A}=\mathrm{NaCl}$ only (control); $\mathrm{B}=3 \mathrm{NaCl}: 1 \mathrm{KCl}$ (wt/wt); $\mathrm{C}=1 \mathrm{NaCl}: 1 \mathrm{KCl}$ (wt/wt); $\mathrm{D}=1 \mathrm{NaCl}: 3 \mathrm{KCl}$ (wt/wt), during storage for $30 \mathrm{~d}$ at $4^{\circ} \mathrm{C}$. Color version available in the online PDF.

presented in Table 4. No significant $(P>0.05)$ difference was observed in LB growth among experimental cheeses at the same storage period. However, the growth of ST, LC, and LA significantly $(P<0.05)$ differed among experimental cheeses. This finding is in accordance with those of Ayyash and Shah (2011d) who reported a significant difference in lactic acid bacteria growth between experimental low-molecular mass chitosans. In the current study, the differences in the bacterial growth were inconsistent during the storage period. Nonetheless, it was obvious that the substitution of $\mathrm{NaCl}$ with $\mathrm{KCl}$ affected $(P<0.05)$ probiotic growth. This may be attributed to the effect of the

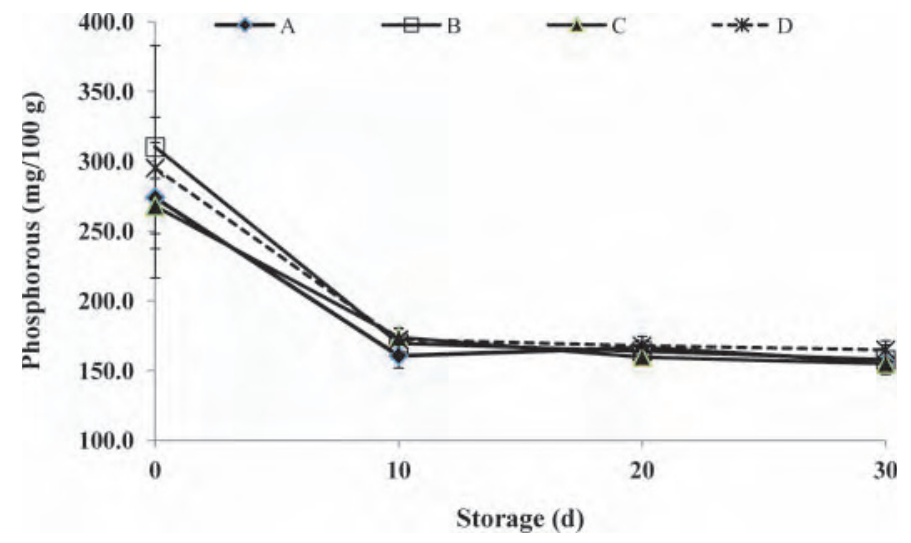

Figure 4. Phosphorous contents of Akawi cheeses stored in 4 levels of $\mathrm{NaCl}$ and $\mathrm{KCl}, \mathrm{A}=\mathrm{NaCl}$ only (control); $\mathrm{B}=3 \mathrm{NaCl}: 1 \mathrm{KCl}$ (wt/ wt); $\mathrm{C}=1 \mathrm{NaCl}: 1 \mathrm{KCl}$ (wt/wt); $\mathrm{D}=1 \mathrm{NaCl}: 3 \mathrm{KCl}$ (wt/wt), during storage for $30 \mathrm{~d}$ at $4^{\circ} \mathrm{C}$. Color version available in the online PDF.

$\mathrm{NaCl} / \mathrm{KCl}$ mixture on the bacterial enzymes activity, which, in turn, affected growth.

\section{Organic Acids Profile}

Table 5 presents citric, lactic, and acetic acid contents (mg/100 g) of Akawi cheeses with 4 different salt treatments stored for $30 \mathrm{~d}$ at $4^{\circ} \mathrm{C}$. Significant $(P<0.05)$ differences were observed in citric, lactic, and acetic acid contents among experimental cheeses at the same storage period. These results may be attributed to the differences in bacterial growth described previously. Citric, lactic, and acetic acids were produced as a result

Table 5. Citric, lactic, and acetic acid contents (mg/100 g; mean values \pm SE of 3 trials) in Akawi cheeses kept in 4 levels of $\mathrm{NaCl}$ and $\mathrm{KCl}$ during storage for $30 \mathrm{~d}$ at $4^{\circ} \mathrm{C}$

\begin{tabular}{|c|c|c|c|c|}
\hline $\begin{array}{l}\text { Storage } \\
\text { (d) }\end{array}$ & $\begin{array}{l}\text { Salt } \\
\text { treatment }^{1}\end{array}$ & Citric acid & Lactic acid & Acetic acid \\
\hline \multirow[t]{4}{*}{0} & A & $181.4 \pm 4.9^{\mathrm{a}}$ & $110.9 \pm 0.8^{\mathrm{a}}$ & $131.2 \pm 2.8^{\mathrm{a}}$ \\
\hline & $\mathrm{B}$ & $178.1 \pm 1.3^{\mathrm{a}}$ & $112.1 \pm 1.6^{\mathrm{a}}$ & $136.7 \pm 2.9^{\mathrm{a}}$ \\
\hline & $\mathrm{C}$ & $142.6 \pm 9.2^{\mathrm{b}}$ & $113.3 \pm 1.5^{\mathrm{a}}$ & $126.3 \pm 3.5^{\mathrm{a}}$ \\
\hline & $\mathrm{D}$ & $136.2 \pm 10.8^{\mathrm{b}}$ & $109.7 \pm 0.9^{\mathrm{a}}$ & $114.3 \pm 3.5^{\mathrm{b}}$ \\
\hline \multirow[t]{4}{*}{10} & $\mathrm{~A}$ & $157.2 \pm 11.1^{\mathrm{a}}$ & $138.7 \pm 30.1^{\mathrm{a}}$ & $114.6 \pm 1.3^{\mathrm{ab}}$ \\
\hline & $\mathrm{B}$ & $159.2 \pm 4.8^{\mathrm{a}}$ & $108.7 \pm 0.1^{\mathrm{a}}$ & $110.5 \pm 3.2^{\mathrm{b}}$ \\
\hline & $\mathrm{C}$ & $170.2 \pm 6.0^{\mathrm{a}}$ & $109.9 \pm 0.5^{\mathrm{a}}$ & $124.9 \pm 1.9^{\mathrm{a}}$ \\
\hline & $\mathrm{D}$ & $172.3 \pm 2.1^{\mathrm{a}}$ & $110.7 \pm 0.1^{\mathrm{a}}$ & $120.2 \pm 5.4^{\mathrm{ab}}$ \\
\hline \multirow[t]{4}{*}{20} & $\mathrm{~A}$ & $188.3 \pm 1.8^{\mathrm{ab}}$ & $110.5 \pm 0.4^{\mathrm{b}}$ & $108.8 \pm 3.6^{\mathrm{b}}$ \\
\hline & $\mathrm{B}$ & $204.4 \pm 3.9^{\mathrm{a}}$ & $113.2 \pm 0.2^{\mathrm{a}}$ & $125.2 \pm 3.9^{\mathrm{a}}$ \\
\hline & $\mathrm{C}$ & $190.6 \pm 0.3^{\mathrm{ab}}$ & $111.2 \pm 0.2^{\mathrm{b}}$ & $111.6 \pm 2.5^{\mathrm{b}}$ \\
\hline & $\mathrm{D}$ & $168.9 \pm 12.4^{\mathrm{b}}$ & $109.0 \pm 0.5^{\mathrm{c}}$ & $109.2 \pm 1.8^{\mathrm{b}}$ \\
\hline \multirow[t]{4}{*}{30} & A & $376.8 \pm 15.4^{\mathrm{b}}$ & $136.1 \pm 3.7^{\mathrm{b}}$ & $282.5 \pm 20.9^{\mathrm{b}}$ \\
\hline & B & $398.1 \pm 4.5^{\mathrm{b}}$ & $136.2 \pm 0.4^{\mathrm{b}}$ & $259.6 \pm 36.7^{\mathrm{b}}$ \\
\hline & $\mathrm{C}$ & $420.8 \pm 12.8^{\mathrm{b}}$ & $144.9 \pm 3.0^{\mathrm{b}}$ & $325.7 \pm 57.7^{\mathrm{ab}}$ \\
\hline & $\mathrm{D}$ & $540.3 \pm 44.3^{\mathrm{a}}$ & $156.5 \pm 5.5^{\mathrm{a}}$ & $454.5 \pm 38.3^{\mathrm{a}}$ \\
\hline
\end{tabular}

${ }^{\mathrm{a}-\mathrm{c}}$ Means within a column and at the same storage time with the same superscript letter did not differ significantly $(P>0.05)$.

${ }^{1}$ Salt treatment: $\mathrm{A}=\mathrm{NaCl}$ only (control); $\mathrm{B}=3 \mathrm{NaCl}: 1 \mathrm{KCl}$ (wt/wt); $\mathrm{C}=1 \mathrm{NaCl}: 1 \mathrm{KCl}$ (wt/wt); D = 1 $\mathrm{NaCl}: 3 \mathrm{KCl}$ (wt/wt). 


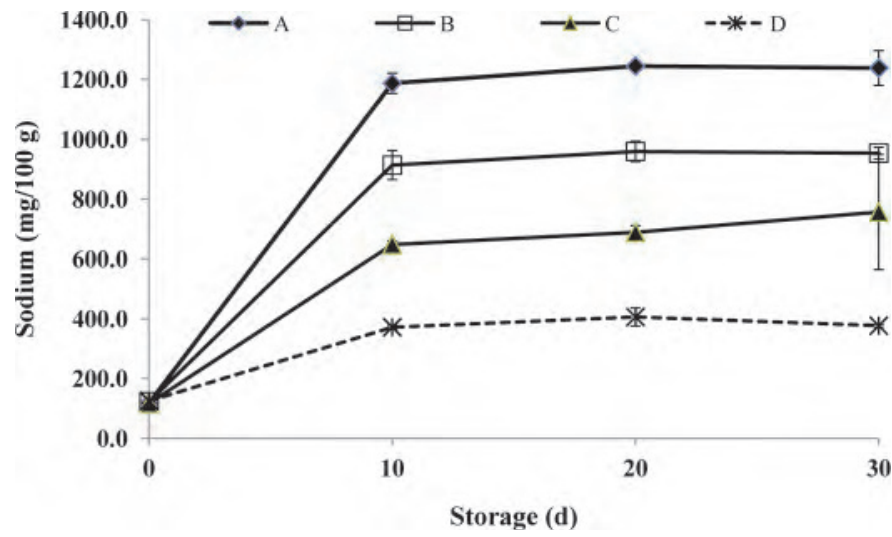

Figure 5. Sodium contents of Akawi cheeses stored in 4 levels of $\mathrm{NaCl}$ and $\mathrm{KCl}, \mathrm{A}=\mathrm{NaCl}$ only (control); $\mathrm{B}=3 \mathrm{NaCl}: 1 \mathrm{KCl}$ (wt/wt); $\mathrm{C}=1 \mathrm{NaCl}: 1 \mathrm{KCl}$ (wt/wt); $\mathrm{D}=1 \mathrm{NaCl}: 3 \mathrm{KCl}$ (wt/wt), during storage for $30 \mathrm{~d}$ at $4^{\circ} \mathrm{C}$. Color version available in the online PDF.

of the bacterial metabolism in cheeses. Hence, organic acid content in Akawi cheese could be affected as a result of the salting treatment, which significantly affected the bacterial growth. In general, ANOVA showed that citric, lactic, and acetic acid contents increased $(P$ $<0.05$ ) during storage in all salt treatments (Table 5 ).

\section{Total and Soluble $\mathrm{Ca}, \mathrm{P}, \mathrm{Na}$, and $\mathrm{K}$ Contents}

The total concentrations of $\mathrm{Ca}, \mathrm{P}, \mathrm{Na}$, and $\mathrm{K}$ in experimental Akawi cheeses during the storage period are shown in Figures 3, 4, 5, and 6, respectively. Calcium and $\mathrm{P}$ contents in experimental cheeses decreased significantly $(P<0.05)$ during the storage period for all

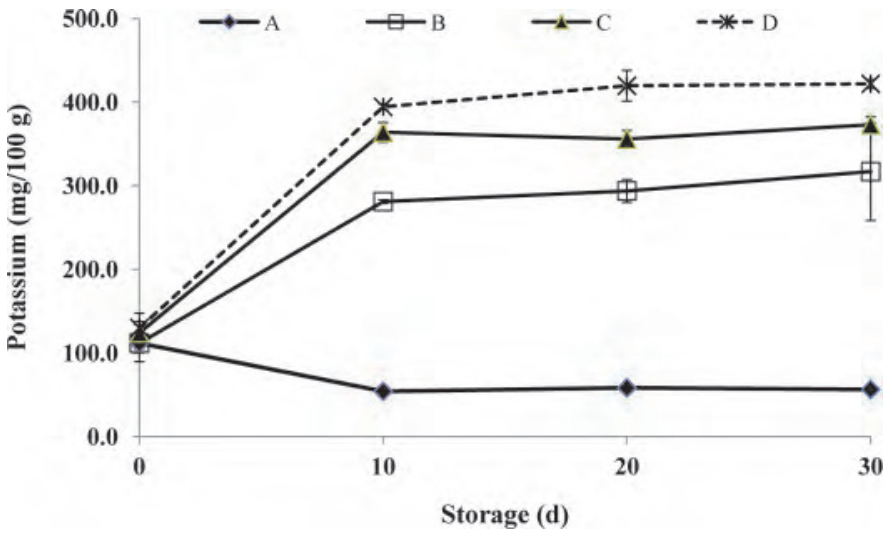

Figure 6. Potassium contents of Akawi cheeses stored in 4 levels of $\mathrm{NaCl}$ and $\mathrm{KCl}, \mathrm{A}=\mathrm{NaCl}$ only (control); $\mathrm{B}=3 \mathrm{NaCl}: 1 \mathrm{KCl}$ (wt/wt); $\mathrm{C}=1 \mathrm{NaCl}: 1 \mathrm{KCl}$ (wt/wt); $\mathrm{D}=1 \mathrm{NaCl}: 3 \mathrm{KCl}$ (wt/wt), during storage for $30 \mathrm{~d}$ at $4^{\circ} \mathrm{C}$. Color version available in the online PDF.

salt treatments. However, $\mathrm{Ca}$ and $\mathrm{P}$ contents differed insignificantly $(P>0.05)$ between Akawi cheeses at the same of storage period (Figures 3 and 4 ). These results agree with those of Ayyash and Shah (2010, 2011b) who reported similar results in Halloumi and Nabulsi cheeses. This reduction may be due to the migration of $\mathrm{Ca}$ and $\mathrm{P}$ toward the brine solution. Significant $(P<$ 0.05 ) differences were found in $\mathrm{Na}$ and $\mathrm{K}$ contents in experimental cheeses at the same storage period (Figures 5 and 6$)$. Sodium contents decreased $(P<0.05)$ in Akawi cheese along with increases in the substitution of $\mathrm{NaCl}$ with $\mathrm{KCl}$, expectedly. The $\mathrm{Na}$ content gradually decreased $(P<0.05)$ in the order treatment $\mathrm{A}>\mathrm{B}>$ $\mathrm{C}>\mathrm{D}$. Figures 5 and 6 show that $\mathrm{Na}$ and $\mathrm{K}$ contents

Table 6. Soluble Ca, K, Na, and $\mathrm{P}$ contents (mg/100 g; mean values $\pm \mathrm{SE}$ of 3 trials) in Akawi cheeses kept in 4 levels of $\mathrm{NaCl}$ and $\mathrm{KCl}$ during storage for $30 \mathrm{~d}$ at $4^{\circ} \mathrm{C}$

\begin{tabular}{|c|c|c|c|c|c|}
\hline $\begin{array}{l}\text { Storage } \\
\text { (d) }\end{array}$ & $\begin{array}{l}\text { Salt } \\
\text { treatment }^{1}\end{array}$ & Soluble Ca & Soluble K & Soluble Na & Soluble P \\
\hline \multirow[t]{3}{*}{0} & $\mathrm{~A}$ & $6.82 \pm 0.1^{\mathrm{a}}$ & $15.47 \pm 0.4^{\mathrm{ab}}$ & $9.41 \pm 0.2^{\mathrm{bc}}$ & $5.30 \pm 0.3^{\mathrm{ab}}$ \\
\hline & $\mathrm{B}$ & $6.82 \pm 0.1^{\mathrm{a}}$ & $14.40 \pm 0.1^{\mathrm{b}}$ & $9.09 \pm 0.0^{\mathrm{c}}$ & $4.93 \pm 0.1^{\mathrm{b}}$ \\
\hline & $\mathrm{D}$ & $6.81 \pm 0.1^{\mathrm{a}}$ & $16.43 \pm 0.2^{\mathrm{a}}$ & $9.97 \pm 0.1^{\mathrm{a}}$ & $5.76 \pm 0.1^{\mathrm{a}}$ \\
\hline \multirow[t]{2}{*}{10} & $\mathrm{~A}$ & $10.91 \pm 0.4^{\mathrm{a}}$ & $8.61 \pm 0.3^{\mathrm{c}}$ & $597.07 \pm 3.9^{\mathrm{a}}$ & $5.75 \pm 0.1^{\mathrm{a}}$ \\
\hline & B & $10.59 \pm 0.1^{\mathrm{ab}}$ & $111.47 \pm 1.0^{\mathrm{a}}$ & $439.20 \pm 19.7^{b}$ & $5.54 \pm 0.2^{\mathrm{a}}$ \\
\hline \multirow{3}{*}{20} & $\mathrm{~B}$ & $7.61 \pm 0.1^{\mathrm{ab}}$ & $87.20 \pm 1.6^{\mathrm{b}}$ & $398.67 \pm 10.5^{\mathrm{b}}$ & $5.75 \pm 0.3^{\mathrm{a}}$ \\
\hline & $\mathrm{C}$ & $6.54 \pm 0.2^{\mathrm{b}}$ & $75.76 \pm 2.1^{\mathrm{c}}$ & $229.33 \pm 4.7^{\mathrm{c}}$ & $5.72 \pm 0.1^{\mathrm{a}}$ \\
\hline & $\mathrm{D}$ & $9.58 \pm 1.7^{\mathrm{a}}$ & $103.81 \pm 0.6^{\mathrm{a}}$ & $108.53 \pm 3.3^{\mathrm{d}}$ & $6.07 \pm 0.2^{\mathrm{a}}$ \\
\hline \multirow[t]{3}{*}{30} & $\mathrm{~A}$ & $9.87 \pm 0.0^{\mathrm{a}}$ & $10.72 \pm 2.1^{\mathrm{c}}$ & $597.87 \pm 17.3^{\mathrm{a}}$ & $5.41 \pm 0.2^{\mathrm{a}}$ \\
\hline & $\mathrm{B}$ & $9.36 \pm 0.4^{\mathrm{ab}}$ & $111.47 \pm 1.0^{\mathrm{a}}$ & $461.60 \pm 6.4^{\mathrm{b}}$ & $5.34 \pm 0.1^{\mathrm{a}}$ \\
\hline & $\mathrm{C}$ & $9.15 \pm 0.1^{\mathrm{ab}}$ & $110.67 \pm 1.0^{\mathrm{a}}$ & $358.13 \pm 56.6^{\mathrm{c}}$ & $5.48 \pm 0.1^{\mathrm{a}}$ \\
\hline
\end{tabular}

\footnotetext{
${ }^{\mathrm{a}-\mathrm{d}}$ Means within a column and at the same storage time with the same superscript letter did not differ significantly $(P>0.05)$.

${ }^{1}$ Salt treatment: $\mathrm{A}=\mathrm{NaCl}$ only (control); $\mathrm{B}=3 \mathrm{NaCl}: 1 \mathrm{KCl}$ (wt/wt); $\mathrm{C}=1 \mathrm{NaCl}: 1 \mathrm{KCl}$ (wt/wt); $\mathrm{D}=1 \mathrm{NaCl}: 3 \mathrm{KCl}$ (wt/wt).
} 
Table 7. Texture profile (mean values $\pm \mathrm{SE}$ of 3 trials) of Akawi cheeses kept in 4 levels of $\mathrm{NaCl}$ and $\mathrm{KCl}$ during storage for $30 \mathrm{~d}$ at $4^{\circ} \mathrm{C}$

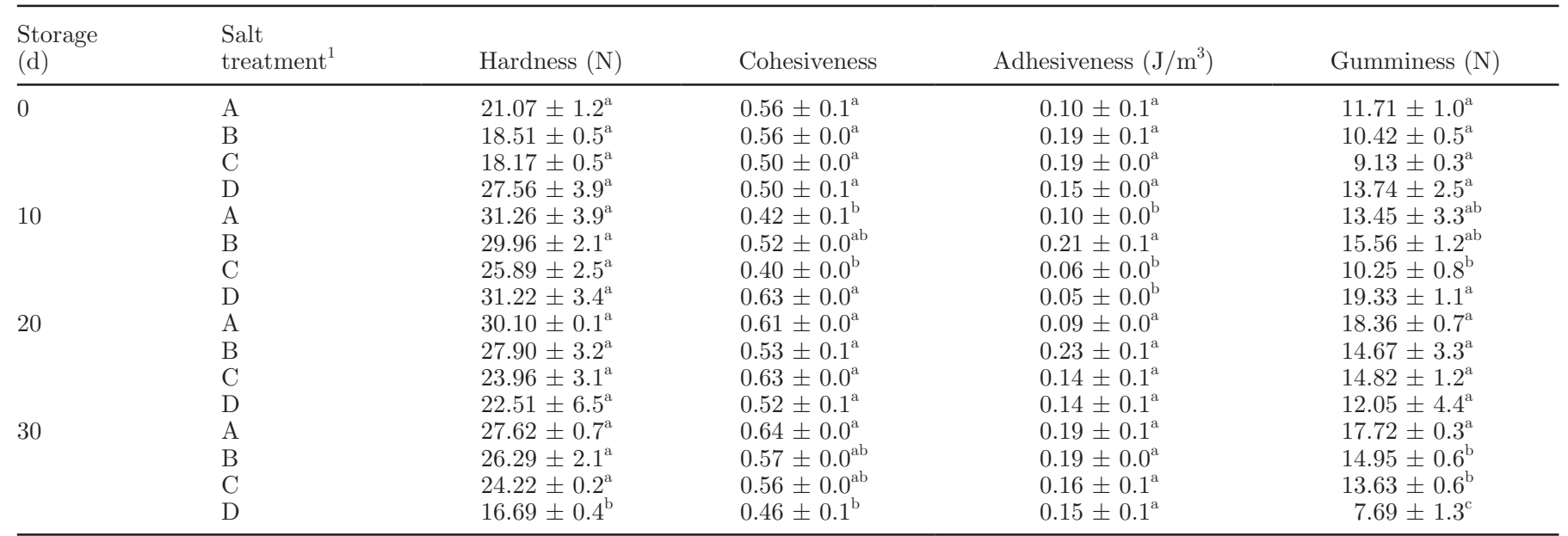

${ }^{\mathrm{a}-\mathrm{c}}$ Means within a column and at the same storage time with the same superscript letter did not differ significantly $(P>0.05)$.

${ }^{1}$ Salt treatment: $\mathrm{A}=\mathrm{NaCl}$ only (control); $\mathrm{B}=3 \mathrm{NaCl}: 1 \mathrm{KCl}$ (wt/wt); C $=1 \mathrm{NaCl}: 1 \mathrm{KCl}$ (wt/wt); $\mathrm{D}=1 \mathrm{NaCl}: 3 \mathrm{KCl}$ (wt/wt).

increased $(P<0.05)$ during the storage period for the same salt treatment. These results are in agreement with those of Ayyash and Shah (2010, 2011b).

Table 6 presents the soluble $\mathrm{Ca}, \mathrm{P}, \mathrm{Na}$, and $\mathrm{K}$ contents $(\mathrm{mg} / 100 \mathrm{~g})$ in experimental cheeses during $30 \mathrm{~d}$ of storage at $4^{\circ} \mathrm{C}$. Soluble $\mathrm{Na}$ and $\mathrm{K}$ contents significantly differed $(P<0.05)$ between the 4 Akawi cheeses at the same storage period. In addition, the soluble $\mathrm{Na}$ and $\mathrm{K}$ content increased $(P<0.05)$ during storage for the same salt treatment. This may be attributed to the significant differences in total $\mathrm{Na}$ and $\mathrm{K}$ (Figures 5 and 6). The behavior of soluble $\mathrm{Na}$ and $\mathrm{K}$ in cheeses should be further investigated. Soluble P content insignificantly differed $(P>0.05)$ among experimental cheeses at the same storage time and at the same salt treatment (Table 6). A significant difference $(P<0.05)$ was observed in soluble $\mathrm{Ca}$ among experimental cheeses at the same storage period. The differences in soluble Ca between Akawi cheeses showed an inconsistent trend, which needs further investigation to understand the behavior of soluble Ca. However, the soluble Ca increased $(P<$ 0.05) in Akawi cheeses during the storage period for the same salt treatment. This result agrees with findings of soluble $\mathrm{Ca}$ in low-moisture Mozzarella cheese salted with $4 \mathrm{NaCl} / \mathrm{KCl}$ mixtures and stored for $27 \mathrm{~d}$ at $4^{\circ} \mathrm{C}$ (Ayyash and Shah, 2011c).

\section{Texture Profile Analysis}

Hardness, cohesiveness, adhesiveness, and gumminess of experimental Akawi cheeses during $30 \mathrm{~d}$ of storage are presented in Table 7 . In general, hardness and adhesiveness showed no significant differences $(P>0.05)$ among experimental cheeses at the same storage period.

Table 8. Sensory evaluation (mean values $\pm \mathrm{SE}$ of 3 trials) of Akawi cheeses kept in 4 levels of $\mathrm{NaCl}$ and $\mathrm{KCl}$ during storage for $30 \mathrm{~d}$ at $4{ }^{\circ} \mathrm{C}$

\begin{tabular}{|c|c|c|c|c|c|c|}
\hline $\begin{array}{l}\text { Storage } \\
\text { (d) }\end{array}$ & $\begin{array}{l}\text { Salt } \\
\text { treatment }^{1}\end{array}$ & Creaminess & Bitterness & Saltiness & Sour-acid & Vinegar \\
\hline \multirow[t]{4}{*}{10} & $\mathrm{~A}$ & $4.1 \pm 0.50^{\mathrm{a}}$ & $1.9 \pm 0.46^{\mathrm{a}}$ & $5.0 \pm 0.63^{\mathrm{a}}$ & $1.8 \pm 0.33^{\mathrm{a}}$ & $1.8 \pm 0.51^{\mathrm{a}}$ \\
\hline & $\mathrm{B}$ & $4.4 \pm 0.52^{\mathrm{a}}$ & $1.8 \pm 0.33^{\mathrm{a}}$ & $4.5 \pm 0.64^{\mathrm{a}}$ & $1.8 \pm 0.42^{\mathrm{a}}$ & $1.8 \pm 0.54^{\mathrm{a}}$ \\
\hline & $\mathrm{C}$ & $4.2 \pm 0.58^{\mathrm{a}}$ & $1.9 \pm 0.46^{\mathrm{a}}$ & $4.4 \pm 0.50^{\mathrm{a}}$ & $2.1 \pm 0.47^{\mathrm{a}}$ & $1.7 \pm 0.42^{\mathrm{a}}$ \\
\hline & $\mathrm{D}$ & $4.6 \pm 0.58^{\mathrm{a}}$ & $2.4 \pm 0.52^{\mathrm{a}}$ & $4.4 \pm 0.72^{\mathrm{a}}$ & $1.7 \pm 0.33^{\mathrm{a}}$ & $1.9 \pm 0.50^{\mathrm{a}}$ \\
\hline \multirow[t]{4}{*}{20} & $\mathrm{~A}$ & $4.5 \pm 0.65^{\mathrm{a}}$ & $2.1 \pm 0.46^{\mathrm{a}}$ & $4.1 \pm 0.53^{\mathrm{a}}$ & $1.9 \pm 0.35^{\mathrm{a}}$ & $1.9 \pm 0.53^{\mathrm{a}}$ \\
\hline & $\mathrm{B}$ & $5.1 \pm 0.60^{\mathrm{a}}$ & $2.1 \pm 0.60^{\mathrm{a}}$ & $3.9 \pm 0.38^{\mathrm{a}}$ & $1.9 \pm 0.46^{\mathrm{a}}$ & $1.8 \pm 0.51^{\mathrm{a}}$ \\
\hline & $\mathrm{C}$ & $4.7 \pm 0.60^{\mathrm{a}}$ & $2.2 \pm 0.51^{\mathrm{a}}$ & $4.7 \pm 0.65^{\mathrm{a}}$ & $2.5 \pm 0.67^{\mathrm{a}}$ & $1.9 \pm 0.46^{\mathrm{a}}$ \\
\hline & $\mathrm{D}$ & $5.0 \pm 0.63^{\mathrm{a}}$ & $2.6 \pm 0.48^{\mathrm{a}}$ & $4.0 \pm 0.49^{\mathrm{a}}$ & $2.1 \pm 0.43^{\mathrm{a}}$ & $1.9 \pm 0.41^{\mathrm{a}}$ \\
\hline \multirow[t]{4}{*}{30} & $\mathrm{~A}$ & $5.3 \pm 0.75^{\mathrm{a}}$ & $2.2 \pm 0.44^{\mathrm{a}}$ & $4.7 \pm 0.58^{\mathrm{a}}$ & $2.1 \pm 0.45^{\mathrm{a}}$ & $1.7 \pm 0.42^{\mathrm{a}}$ \\
\hline & B & $5.2 \pm 0.61^{\mathrm{a}}$ & $1.9 \pm 0.35^{\mathrm{a}}$ & $4.1 \pm 0.48^{\mathrm{a}}$ & $2.1 \pm 0.41^{\mathrm{a}}$ & $2.1 \pm 0.50^{\mathrm{a}}$ \\
\hline & $\mathrm{C}$ & $4.9 \pm 0.68^{\mathrm{a}}$ & $1.9 \pm 0.41^{\mathrm{a}}$ & $3.9 \pm 0.50^{\mathrm{a}}$ & $2.0 \pm 0.42^{\mathrm{a}}$ & $2.3 \pm 0.56^{\mathrm{a}}$ \\
\hline & $\mathrm{D}$ & $4.7 \pm 0.76^{\mathrm{a}}$ & $2.1 \pm 0.41^{\mathrm{a}}$ & $3.7 \pm 0.65^{\mathrm{a}}$ & $1.9 \pm 0.38^{\mathrm{a}}$ & $2.3 \pm 0.54^{\mathrm{a}}$ \\
\hline
\end{tabular}

${ }^{\mathrm{a}}$ Means within a column and at the same storage time with the same superscript letter did not differ significantly $(P>0.05)$.

${ }^{1}$ Salt treatment: $\mathrm{A}=\mathrm{NaCl}$ only (control); $\mathrm{B}=3 \mathrm{NaCl}: 1 \mathrm{KCl}$ (wt/wt); C = $1 \mathrm{NaCl}: 1 \mathrm{KCl}$ (wt/wt); D = $1 \mathrm{NaCl}: 3 \mathrm{KCl}$ (wt/wt). 
The occasional significant difference in hardness at $\mathrm{d} 30$ and in adhesiveness at $\mathrm{d} 10$ may be attributed to differences between cheese loaves but was not due to salt treatment (Table 7). These results are in accordance with those of Ayyash et al. (2011) who reported similar results in Halloumi cheese. A significant difference in cohesiveness existed between experimental cheeses at d 10 and 30 of storage. A similar trend was observed in gumminess, which showed a significant difference between Akawi cheeses at d 10 and 30 of storage. We assume that these differences in cohesiveness and gumminess may be attributed to differences between cheese loaves but not due to salt treatments.

\section{Sensory Properties}

Sensory attribute scores (creaminess, bitterness, saltiness, sour-acid, and vinegar) of the 4 experimental Akawi cheeses are presented in Table 8. No significant differences $(P>0.05)$ existed in creaminess, bitterness, saltiness, sour-acid, and vinegar among experimental Akawi cheeses at the same storage period. These results are in agreement with those of Katsiari et al. (1997, 1998) who reported no significant difference in sensory attributes between cheeses made with a $\mathrm{NaCl} / \mathrm{KCl}$ mixture compared with the control for Feta and Kefalograviera cheeses. This suggests that Akawi cheeses salted with the $\mathrm{NaCl} / \mathrm{KCl}$ mixture had similar sensory attributes as those of the control. Treatment D numerically received lower saltiness scores compared with the other treatments. The saltiness score of treatment D decreased $(P>0.05)$ during the storage period (Table $8)$. Vinegar scores increased $(P>0.05)$ at the end of the storage period. This result was consistent with the increase in acetic acid content occurring during storage.

\section{CONCLUSIONS}

The effect of partial substitution of $\mathrm{NaCl}$ and $\mathrm{KCl}$ significantly affected microbial growth and proteolytic activity. The latter is due to the action of proteolytic enzymes. Salt treatment insignificantly affected the texture profile of Akawi cheese. The effect of salt treatment on chemical composition of Akawi cheese was insignificant. Further studies are needed to understand the role of $\mathrm{K}$ in cheese and its effect on proteolytic enzymes.

\section{REFERENCES}

Abd El-Salam, M. H., and E. Alichanidis. 2004. Cheese varieties ripened in brine. Pages 227-249 in Cheese: Chemistry, Physics and Microbiology. Major Cheese Groups, Vol. 2. 3rd ed. P. F. Fox, P.
L. H. McSweeney, T. M. Cogan, and T. P. Guinee, ed. Elsevier Academic Press, London, UK.

AOAC (Association of Official Analytical Chemists). 1995. Official Methods of Analysis. AOAC International, Arlington, VA.

Armenteros, M., M. C. Aristoy, J. M. Barat, and F. Toldrá. 2009. Biochemical changes in dry-cured loins salted with partial replacements of $\mathrm{NaCl}$ by KCl. Food Chem. 117:627-633.

Ash, A., and A. Wilbey. 2010. The nutritional significance of cheese in the UK diet. Int. J. Dairy Technol. 63:305-319.

Ayyash, M. M., and N. P. Shah. 2010. Effect of partial substitution of $\mathrm{NaCl}$ with $\mathrm{KCl}$ on Halloumi cheese during storage: Chemical composition, lactic bacterial count, and organic acids production. J. Food Sci. 75:C525-C529.

Ayyash, M. M., and N. P. Shah. 2011a. Effect of partial substitution of $\mathrm{NaCl}$ with $\mathrm{KCl}$ on proteolysis of Halloumi cheese. J. Food Sci. 76:C31-C37.

Ayyash, M. M., and N. P. Shah. 2011b. The effect of substituting $\mathrm{NaCl}$ with $\mathrm{KCl}$ on Nabulsi cheese: Chemical composition, total viable count, and texture profile. J. Dairy Sci. 94:2741-2751.

Ayyash, M. M., and N. P. Shah. 2011c. The effect of substitution of $\mathrm{NaCl}$ with $\mathrm{KCl}$ on chemical composition and functional properties of low-moisture Mozzarella cheese. J. Dairy Sci. 94:3761-3768.

Ayyash, M. M., and N. P. Shah. 2011d. Proteolysis of low-moisture Mozzarella cheese as affected by substitution of $\mathrm{NaCl}$ with $\mathrm{KCl}$. J. Dairy Sci. 94:3769-3777.

Ayyash, M. M., F. Sherkat, P. Francis, R. P. Williams, and N. P. Shah. 2011. The effect of sodium chloride substitution with potassium chloride on texture profile and microstructure of Halloumi cheese. J. Dairy Sci. 94:37-42.

Church, F. C., H. E. Swaisgood, D. H. Porter, and G. L. Catignani. 1983. Spectrophotometric assay using $o$-phthaldialdehyde for determination of proteolysis in milk and isolated milk proteins. J. Dairy Sci. 66:1219-1227.

Delahunty, C. M., and M. A. Drake. 2004. Sensory character of cheese and its evaluation. Pages 455-487 in Cheese: Chemistry, Physics and Microbiology. Vol. 1. P. F. Fox, P. L. H. McSweeney, T. M. Cogan, and T. P. Guinee, ed. Elsevier Academic Press, London, UK.

Folkertsma, B., and P. F. Fox. 1992. Use of the Cd-ninhydrin reagent to assess proteolysis in cheese during ripening. J. Dairy Res. $59: 217-224$

Guinee, T. P. 2004a. Salting and the role of salt in cheese. Int. J. Dairy Technol. 57:99-109.

Guinee, T. P. 2004b. Scrap the salt. Dairy Ind. Int. 69:36-38.

Heaney, R. P. 2006. Role of dietary sodium in osteoporosis. J. Am. Coll. Nutr. 25:271S-276S.

ISO/IDF (International Organization for Standardization/International Dairy Federation). 2002. Milk and milk products - General guidance for the preparation of test samples, initial suspensions and decimal dilutions for microbiological examination (EN ISO 8261:2002). ISO 8261/IDF 122. ISO, Geneva, Switzerland.

Katsiari, M. C., E. Alichanidis, L. P. Voutsinas, and I. G. Roussis 2001. Proteolysis in reduced sodium Kefalograviera cheese made by partial replacement of $\mathrm{NaCl}$ with $\mathrm{KCl}$. Food Chem. 73:31-43

Katsiari, M. C., L. P. Voutsinas, E. Alichanidis, and I. G. Roussis. 1997. Reduction of sodium content in Feta cheese by partial substitution of $\mathrm{NaCl}$ by KCl. Int. Dairy J. 7:465-472.

Katsiari, M. C., L. P. Voutsinas, E. Alichanidis, and I. G. Roussis. 1998. Manufacture of Kefalograviera cheese with less sodium by partial replacement of $\mathrm{NaCl}$ with $\mathrm{KCl}$. Food Chem. 61:63-70.

Kotchen, T. A. 2005. Contributions of sodium and chloride to NaClinduced hypertension. Hypertension 45:849-850.

Kuchroo, C. N., and P. F. Fox. 1982. Soluble nitrogen in Cheddar cheese: Comparison of extraction procedures. Milchwissenschaft $53: 262-269$.

Massey, L. K. 2005. Effect of dietary salt intake on circadian calcium metabolism, bone turnover, and calcium oxalate kidney stone risk in postmenopausal women. Nutr. Res. 25:891-903.

Meneton, P., L. Lafay, A. Tard, A. Dufour, J. Ireland, J. Ménard, and J. L. Volatier. 2009. Dietary sources and correlates of sodium and 
potassium intakes in the French general population. Eur. J. Clin. Nutr. 63:1169-1175.

NHMRC (National Health and Medical Research Council). 2003. Dietary Guidelines for Children and Adolescents in Australia. Apr. 10, 2003. http://www.nhmrc.gov.au/_files_nhmrc/file/publications/synopses/n34.pdf.

Ong, L. 2007. Influence of probiotic organisms on proteolytic pattern, release of bioactive compounds and sensory attributes of cheddar cheese. PhD Thesis. Victoria University, Melbourne, Victoria, Australia.

Ong, L., A. Henriksson, and N. P. Shah. 2006. Development of probiotic Cheddar cheese containing Lactobacillus acidophilus, Lb. casei, Lb. paracasei and Bifidobacterium spp. and the influence of these bacteria on proteolytic patterns and production of organic acid. Int. Dairy J. 16:446-456.
Penner, S. B., N. R. C. Campbell, A. Chockalingam, K. Zarnke, and B. Van Vliet. 2007. Dietary sodium and cardiovascular outcomes: A rational approach. Can. J. Cardiol. 23:567-572.

Pons, M., and S. M. Fiszman. 1996. Instrumental texture profile analysis with particular reference to gelled systems. J. Texture Stud. $27: 597-624$.

Reddy, K. A., and E. H. Marth. 1991. Reducing the sodium content of foods: A review. J. Food Prot. 54:138-150.

Tamime, A. Y. 2006. Brined Cheeses. Society of Dairy Technology book series. Blackwell Publishing, Oxford, UK.

WHO (World Health Organization). 2007. Reducing salt intake in populations: Report of a WHO forum and technical meeting. http:// www.who.int/dietphysicalactivity/reducingsaltintake_EN.pdf. 